\title{
Effect of Using Aloe vera (Aloe barbadensis) and Neem (Azadirachta indica) Leaves Powder on Blood Biochemical Parameters in Vanraja Poultry Birds
}

\author{
S. D. Gadekar*, S. D. Chavan and S. R. Shegokar \\ Department of Animal Husbandry and Dairy science, Dr. Panjabrao Deshmukh Krishi \\ Vidyapeeth, Akola, (M. S.), India \\ *Corresponding author
}

Keywords

Aloe vera, Neem, Blood biochemical, Vanraja

Article Info

Accepted:

12 September 2020 Available Online: 10 October 2020

\section{A B S T R A C T}

To determine the effect of using Aloe vera and Neem leaves powder on carcass characteristics and some blood biochemical in vanraja poultry birds, a total 270 a day old chicks with an average identical weight were divided into 9 treatments with 3 replicates as factorial randomized block design experiment. The birds were fed by basal diet as control diet, Aloe vera, Neem leaves powder based diet and different combinations of aloe vera and neem leaves powder. On the basis of data obtained on haemato-biochemical parameters it was observed that highest count for serum total protein, albumin, globulin, cholesterol, serum HDL cholesterol, serum LDL cholesterol, triglycerides, uric acid and creatinine was noticed in $\mathrm{T}_{6}$ $(2.80 \mathrm{mg} / \mathrm{dl}), \mathrm{T}_{3}(1.52 \mathrm{mg} / \mathrm{dl}), \mathrm{T}_{1}(1.69 \mathrm{mg} / \mathrm{dl}), \mathrm{T}_{1}(121.57 \mathrm{mg} / \mathrm{dl}), \mathrm{T}_{7}(33.41$ $\mathrm{mg} / \mathrm{dl}), \mathrm{T}_{6}(56.27 \mathrm{mg} / \mathrm{dl}), \mathrm{T}_{1}(101.17 \mathrm{mg} / \mathrm{dl}) . \mathrm{T}_{1}(5.73 \mathrm{mg} / \mathrm{dl}), \mathrm{T}_{1}(0.89 \mathrm{mg} / \mathrm{dl})$ and $\mathrm{T}_{6}(234.97 \mathrm{mg} / \mathrm{dl})$ respectively. As result relevant from this study using of Aloe vera and Neem leaves powder in diet may be useful and have significantly effects on some blood biochemical parameters on Vanraja poultry birds.

\section{Introduction}

Poultry farming is the raising of domesticated birds such as chickens, Duck, Turkey, and Gees for the purpose of meat or eggs for feed. Poultry industry is a fast growing segment of the agriculture sector in the world. Modern intensive poultry industry demands more rapid growth in a confined housing environment which leads to greater susceptibility to stress in birds.

Poultry industry has made a tremendous and remarkable progress evolving from a small scale backyard venture to the status of commercial, full fledge, self-sufficient and most progressive agro based industry and become an attractive enterprise particularly 
because of the small capital investment, increased returns, quick turn over, comparatively less risk involved, low land requirement, ease of production and high feed efficiency. Due to increasing demand for poultry meat, short supply of mutton and limited acceptability of beef and pork in some countries as considering of religious and cultural points like India. The poultry production is under rapid expansion in the world. Chickens are much more prolific than other livestock and through careful scientific breeding policies; they have become efficient converters of vegetables protein into high quality animal protein food for human consumption.

Feed supplement and feed additives has served the purpose of best production efficiencies over the years. Potential of birds is fully utilized by such feed formulation and feeding practices. At present numbers of feed additives are used to feed broiler birds for the purpose of increase in body weight gain and improve feed efficiency (FCR). However, availability of quality feed at the reasonable cost is key to successful poultry operation (Basak et al., 2002). In view of this to overcome problems of quality feed it is prime important to add some feed additives as a growth promoters.

However some additives like hormones, probiotics, antibiotics and others with the aim to increase the feed efficiency, have residual effects. They leave their residue in meat and egg. Among all these, herbal feed additives are better for feeding of poultry to improve weight gain, feed efficiency and feed intake. These herbal feed additives have no side effects on the health of birds. The dietary use of herbal growth promoter increases the performance of poultry by increasing live weight gain and FCR (Prasad and Sen. 1993, Samarth et al., 2002). In this regards objectives are set to study the use of certain growth promoting herbal feed additives like Aloe vera and Neem.

\section{Materials and Methods}

\section{Birds and diets}

The experiment was conducted on 270 , day old Vanraja chicks, the birds were from the same hatch and were reared under uniform management condition. On arrival, the chicks were weighed individually and randomly divided into nine treatments with three replications, each replication has ten birds.

For the experiment, commercial pre starter, starter and finisher feed were used as basal diet, used as basal diet,

\section{Chemical composition of herbal feed additives (\% DM basis)}

Aloe vera powder used in present investigation contained 83.61, 6.86, 2.91, 73.35 , and 16.88 per cent of dry matter, crude protein crude fat, crude fibre and total ash respectively. Similarly, Neem leaves powder contained 92.40, 20.68, 4.13, 16.60 and 7.10 per cent of dry matter, crude protein, crude fat, crude fibre and total ash respectively.

Preparation of Aloe vera powder the leaves were thoroughly wash with tap water, then slicing of leaves were done followed by drying of Aloe vera slices in desiccant dehumidified air dryer at temperature of 60$65{ }^{0} \mathrm{C}$ and $\mathrm{RH}$ of 18 per cent then dehydrated slices were ground in low temperature grinder to obtain Aloe vera leaves powder, at Department of Agriculture Processing Engineering, Dr, P.D.K.V., Akola. The powder was stored in air tight cellophane bag as stock sample in refrigerator for further analysis. The fresh, clean and succulent green Neem leaves were put in tray for drying and these fresh leaves were keep in mechanical 
tray dryer machine for drying at $40^{\circ} \mathrm{C}$ for $2-4$ hours at Department of Agriculture Processing Engineering, Dr, P.D.K.V., Akola.

\section{Collection of blood samples}

At the end of experiment, one bird from each replication was randomly picked up and blood samples were collected for hematological and serum biochemical analysis.

The blood samples were collected at the end of $8^{\text {th }}$ week of age from wing vein with syringe from one bird in each replication. The blood collected in sterilized glass test tube kept in a slant position and serum was separated. All the serum samples was stored in deep freezed at $20^{\circ} \mathrm{C}$ until processed.

All samples of serum were analyzed at department of Veterinary Biochemistry, PGI, VAS, MAFSU, Akola.

\section{Statistical analysis}

The statistical analysis of the data obtained during experimental period was carried out as per Snedecor and Cochran (1994) using Factorial Randomized Block Design and Randomized Block Design.

\section{Results and Discussion}

\section{Serum biochemical parameters (A)}

\section{Total protein}

Proteins are important building blocks of all cells and tissues. Proteins are necessary for your body's growth, development, and health.

The average total protein level $(\mathrm{g} / \mathrm{dl})$ in different groups is presented in Table 3 .

From the data, it was observed that the total protein level was 3.11, 3.03, 3.01, 2.90, 2.83,
2.80, 2.76, 2.68 and $2.54 \mathrm{~g} / \mathrm{dl}$ for the treatment groups $\mathrm{T}_{1}, \mathrm{~T}_{2}, \mathrm{~T}_{3}, \mathrm{~T}_{4}, \mathrm{~T}_{5}, \mathrm{~T}_{6}, \mathrm{~T}_{7}, \mathrm{~T}_{8}$ and $\mathrm{T}_{9}$, respectively. Thus, there was significant $(\mathrm{P}<0.05)$ decrease in total protein level in all treatment groups as compared to treatment group $\mathrm{T}_{1}$. It was revealed that the total protein count of treatment group $\mathrm{T}_{1}$ (3.11) was significantly higher than all groups. All treatments are at par with each other.

The results of the present study with respect on total protein were in agreement with Fallah (2014) reported that the higher total protein concentration was observed with addition of aloe vera gel and garlic powder in comparison to control group, similarly Shihab et al., (2017) study the impact of supplementation neem powder (Azadirachta indica) to diet of broiler and found significant difference $(\mathrm{P}<0.05)$ between the control and all experimental treatments in total protein concentration, it record $(21.51) \mathrm{mg} / 100 \mathrm{ml}$ compared with other treatments $\left(\mathrm{T}_{2}, \mathrm{~T}_{3}\right.$ and $\mathrm{T}$ 4) as it was (29.06, 32.16 and 24.96) $\mathrm{mg} / 100 \mathrm{ml}$, also Nodu et al., (2016) analyses on broiler chickens administrated with Azadirachta indica leaf meal extract at graded levels and found were significantly $(\mathrm{P}<0.05)$ increases the total protein concentration in broilers. They reported that the total protein range was between 54 and $59 \mu / \mathrm{l}$.

\section{Albumin (g/dl)}

Proteins are important building blocks of all cells and tissues. Proteins are necessary for your body's growth, development, and health. Albumin proteins keep fluid from leaking out of your blood vessels.

From the data, it was observed that the albumin was 1.41, 1.39, 1.52, 1.49, 1.39, 1.50, $1.40,1.41$ and $1.37 \mathrm{~g} / \mathrm{dl}$ for the treatment groups $\mathrm{T}_{1}, \mathrm{~T}_{2}, \mathrm{~T}_{3}, \mathrm{~T}_{4}, \mathrm{~T}_{5}, \mathrm{~T}_{6}, \mathrm{~T}_{7}, \mathrm{~T}_{8}$ and $\mathrm{T}_{9}$, respectively. Thus, there was no significant 
( $P>0.05)$ decrease in albumin count in all treatment groups as compared to treatment groups. It was revealed that the total protein count of treatment group $\mathrm{T}_{3}$ (1.52) was significantly higher than all groups. The results of the present study with respect on albumin concentration were in agreement with Singh et al., (2013) had showed no significant differences in the levels of total protein, albumin, globulin and $\mathrm{A} / \mathrm{G}$ ratio and found albumin concentration in treatment control (1.82), T2 (1.80 and T3 (1.90) g/dl, also Nodu et al., (2016); Trincha et al., (2012) they reported there were no significant $(\mathrm{P}>0.05)$ differences observed in albumin concentration and all other serum biochemistry assay, observed values are in tandem with normal ranges reported for healthy birds and recommended that the neem extract as supplement for antibiotic in broiler production is both safe and healthy.

\section{Globulin}

Proteins are important building blocks of all cells and tissues. Proteins are necessary for your body's growth, development, and health. Globulin proteins play an important role in your immune system.

From the data, it was observed that the globulin count was $1.69,1.63,1.48,1.40$, $1.44,1.29,1.36,1.24$ and $1.17 \mathrm{~g} / \mathrm{dl}$ for the treatment groups $\mathrm{T}_{1}, \mathrm{~T}_{2}, \mathrm{~T}_{3}, \mathrm{~T}_{4}, \mathrm{~T}_{5}, \mathrm{~T}_{6}, \mathrm{~T}_{7}, \mathrm{~T}_{8}$ and $\mathrm{T}_{9}$, respectively. Thus, there was significant $(\mathrm{P}<0.05)$ difference in globulin concentration within all treatment groups. It was revealed that the globulin concentration of treatment group $\mathrm{T}_{1} \quad(1.69) \mathrm{g} / \mathrm{dl}$ was significantly higher than all groups and lower globulin concentration was found in treatment $\mathrm{T}_{9}(1.17) \mathrm{g} / \mathrm{dl}$.

The results of the present study with respect on globulin concentration were in agreement with Shihab et al., (2017) reported significant differences among treatment at first period of experiment the impact of neem powder on concentration of globulin level, there were significant differences $(\mathrm{P}<0.05)$ between treatment group T3 was superior significantly $(\mathrm{P}<0.05)$ contrast of control it record (12.00) $\mathrm{mg} / 100 \mathrm{ml}$, in the first period, there are significant differences with other treatments and results refer to significant differences $(\mathrm{P}<0.05)$ between third treatment and treatment was superior to the others in second period and recording (14.50) $\mathrm{mg} / 100 \mathrm{ml}$ compared to other treatments, also Singh et al., (2013) had showed no significant differences in the levels of total protein, albumin, globulin and $\mathrm{A} / \mathrm{G}$ ratio and found globulin concentration in treatment control (2.07), $\mathrm{T}_{2}$ (2.10 and $\mathrm{T}_{3}$ (2.12) g/dl, similarly Nodu et al., (2016); Trincha et al., (2012) they reported there were no significant $(\mathrm{P}>0.05)$ differences observed in globulin concentration and all other serum biochemistry assay.

\section{Serum biochemical parameters $(B)$}

\section{Cholesterol}

Cholesterol is essential for making the cell membrane and cell structures and is vital for synthesis of hormones, vitamin D and other substances. Cell membrane synthesis Cholesterol helps to regulate membrane fluidity over the range of physiological temperatures. Cholesterol also helps your organs function properly. The high cholesterol results in develops symptoms of heart disease, stroke, or atherosclerosis in other blood vessels, such as left-sided chest pain, pressure, or fullness, dizziness, unsteady gait, slurred speech or pain in the lower legs.

From the data, it was observed that the cholesterol count was 121.57, 118.93, 99.75, 102.20, 92.57, 104.57, 107.17, 97.04 and $99.71 \mathrm{mg} / \mathrm{dl}$ for the treatment groups $\mathrm{T}_{1}, \mathrm{~T}_{2}$, 
$\mathrm{T}_{3}, \mathrm{~T}_{4}, \mathrm{~T}_{5}, \mathrm{~T}_{6}, \mathrm{~T}_{7}, \mathrm{~T}_{8}$ and $\mathrm{T}_{9}$, respectively. Thus, there was significant reduction $(\mathrm{P}<0.05)$ in serum cholesterol values in $\mathrm{T}_{5}$ (92.57) $\mathrm{mg} / \mathrm{dl}, \mathrm{T}_{8}$ (97.04) $\mathrm{mg} / \mathrm{dl}, \mathrm{T}_{9}(99.71) \mathrm{mg} / \mathrm{dl}$ and $\mathrm{T}_{4}(102.20) \mathrm{mg} / \mathrm{dl}$ as compared to other experimental treatments and treatment $\mathrm{T}_{1}$ (121.57) $\mathrm{mg} / \mathrm{dl}$ showed highest cholesterol level as compared to other treatments. $\mathrm{T}_{1}$ (121.57) $\mathrm{mg} / \mathrm{dl}$ was significantly higher than all other groups and lower cholesterol concentration was found in treatment $T_{5}$ (92.57) $\mathrm{mg} / \mathrm{dl}$. All treatments are at par with each other.

\section{Serum HDL cholesterol}

High Density Lipoprotein (HDL) is the "good," healthy kind of cholesterol. Your body needs some cholesterol to make hormones, vitamin D, and digestive fluids.

From the data, it was observed that the HDL count was 28.86, 29.08, 31.73, 32.42, 33.46, $33.13,33.41,33.18$ and $32.01 \mathrm{mg} / \mathrm{dl}$ for the treatment groups $\mathrm{T}_{1}, \mathrm{~T}_{2}, \mathrm{~T}_{3}, \mathrm{~T}_{4}, \mathrm{~T}_{5}, \mathrm{~T}_{6}, \mathrm{~T}_{7}, \mathrm{~T}_{8}$ and $\mathrm{T}_{9}$, respectively. Thus, there was significant increase $(\mathrm{P}<0.05)$ in high density lipoprotein (HDL) in all groups as compared to control. Mehala et al., (2008), and Eevuri et al., (2013) reported no significant difference among the treatment groups by dietary inclusion of aloe vera and Curcuma longa and its combinations on serum total cholesterol, HDL cholesterol, LDL cholesterol level.

\section{Serum LDL cholesterol}

Low Density Lipoprotein (LDL) cholesterol can build up in arteries and form fatty, waxy deposits called plaques.

It was observed that the LDL was 51.30, $48.26,47.60,47.20,47.60,42.70,41.43$, 40.60 , and $40.20 \mathrm{mg} / \mathrm{dl}$ for the treatment groups $\mathrm{T}_{1}, \mathrm{~T}_{2}, \mathrm{~T}_{3}, \mathrm{~T}_{4}, \mathrm{~T}_{5}, \mathrm{~T}_{6}, \mathrm{~T}_{7}, \mathrm{~T}_{8}$ and $\mathrm{T}_{9}$, respectively. Treatment $\mathrm{T}_{1} \quad(51.30) \mathrm{mg} / \mathrm{dl}$ showed the highest value LDL cholesterol and $\mathrm{T}_{9}(40.20) \mathrm{mg} / \mathrm{dl}$ showed the lowest value. The result of the current study with respect to LDL cholesterol values were in agreement with The result of present study were in agreement with Fallah (2014) reported significant $(\mathrm{P}<0.05)$ differences in total cholesterol, HDL, LDL concentration compared to control group.

\section{Serum biochemical parameters $(C)$}

\section{Triglycerides}

Triglycerides and cholesterol are both types of fat in your blood known as lipids. Triglycerides provide much of the energy for cell function and metabolism of alcohol, and cholesterol is used to build cells and several hormones. Triglycerides provide your body with energy, but their main function is to store energy for later use. The food you eat contains calories in the form of carbohydrates, protein and fat.

The minimum tryglyceride level was found in $\mathrm{T}_{6}$ (79.89) $\mathrm{mg} / \mathrm{dl}$. the chicks fed ration containing 1 per cent Aloe vera powder +1 per cent Neem leaves powder. The chicks fed on rations containing Aloe vera and Neem leaf powder had significantly $(\mathrm{P}<0.05)$ less value of blood triglycerides compared with control. All treatments were at par with each other. This might be due to increase the level of Aloe vera and Neem leaf powder. The reduction in triglyceride with supplementing Aloe vera in broiler ration has also been reported by Fallah (2014), similarly Ismail (2017); Sonhafouo (2019) reported that serum triglyceride level showed highly significant decrease $(\mathrm{P}<0.05)$ administrated with neem leaves aqueous extract.

\section{Uric acid}

Uric acid is formed in the liver and excreted by kidneys. Birds are uricotelic (excreting 
nitrogen mostly in the form of uric acid birds are typical uricotelic animals) lack the enzyme uricase and this along with the process of water conservation, allows them to excrete urine in the form of semi-solid uric acid in the faeces. Uric acid is a useful diagnostic tool as screening for most of purine metabolic disorders. The importance of uric acid measurement in plasma and urine with respect of metabolic disorders is highlighted. Not only gout and renal stones are indications to send blood to the laboratory for uric acid examination (Table 1-5).

Table.1 Per cent chemical composition of experimental standard ration on dry matter basis

\begin{tabular}{|c|l|c|c|c|}
\hline Sr. & \multicolumn{1}{|c|}{ Nutrients } & \multicolumn{3}{|c|}{ Per cent in ration } \\
\cline { 3 - 5 } No. & & Pre-starter & Starter & Finisher \\
\hline $\mathbf{1}$ & Crude protein & 22 & 20 & 18 \\
\hline $\mathbf{2}$ & Crude fibre & 6.0 & 6.0 & 5.5 \\
\hline $\mathbf{3}$ & Ether extract & 62.2 & 65 & 67.5 \\
\hline $\mathbf{4}$ & Total ash & 6.5 & 6.0 & 5.0 \\
\hline $\mathbf{5}$ & Acid insoluble ash & 1.50 & 2.0 & 2.0 \\
\hline $\mathbf{6}$ & Calcium & 0.5 & 1.0 & 0.9 \\
\hline $\mathbf{7}$ & Phosphorous & 2600 & 0.5 & 0.5 \\
\hline $\mathbf{8}$ & Metabolizable energy & & 2700 & 2800 \\
\hline $\mathbf{9}$ & (kcal/kg) & $118.18: 1$ & $135: 1$ & $155.55: 1$ \\
\hline
\end{tabular}

Table.2 Chemical compositions of herbal feed additives (\% DM basis) Dietary treatments

\begin{tabular}{|c|c|c|}
\hline Parameter & Aloe vera leaf powder & Neem leaf powder \\
\hline Dry matter & 83.61 & 92.40 \\
\hline Crude protein & 6.86 & 20.68 \\
\hline Crude fat & 2.91 & 4.13 \\
\hline Crude fibre & 73.35 & 16.60 \\
\hline Ash & 16.88 & 7.10 \\
\hline
\end{tabular}

Dietary treatments

\begin{tabular}{|l|l|l|l|l|l|l|l|}
\hline $\mathbf{T}_{\mathbf{1}}$ & Standard Ration & Control & & & & & \\
\hline $\mathbf{T}_{\mathbf{2}}$ & Standard Ration & + & $\mathbf{1 \%}$ & $\mathbf{A V P}$ & & & \\
\hline $\mathbf{T}_{\mathbf{3}}$ & Standard Ration & + & $\mathbf{2 \%}$ & $\mathbf{A V P}$ & & & \\
\hline $\mathbf{T}_{\mathbf{4}}$ & Standard Ration & + & $\mathbf{1 \%}$ & $\mathbf{N L P}$ & & & \\
\hline $\mathbf{T}_{\mathbf{5}}$ & Standard Ration & + & $\mathbf{1 . 5 \%}$ & $\mathbf{N L P}$ & & & \\
\hline $\mathbf{T}_{\mathbf{6}}$ & Standard Ration & + & $\mathbf{1 \%}$ & $\mathbf{A V P}$ & + & $\mathbf{1 \%}$ & $\mathbf{N L P}$ \\
\hline $\mathbf{T}_{\mathbf{7}}$ & Standard Ration & + & $\mathbf{1 \%}$ & $\mathbf{A V P}$ & + & $\mathbf{1 . 5 \%}$ & $\mathbf{N L P}$ \\
\hline $\mathbf{T}_{\mathbf{8}}$ & Standard Ration & + & $\mathbf{2 \%}$ & $\mathbf{A V P}$ & + & $\mathbf{1 \%}$ & $\mathbf{N L P}$ \\
\hline $\mathbf{T}_{\mathbf{9}}$ & Standard Ration & + & $\mathbf{2 \%}$ & $\mathbf{A V P}$ & + & $\mathbf{1 . 5 \%}$ & $\mathbf{N L P}$ \\
\hline
\end{tabular}

Where, AVP - Aloe vera Powder

NLP- Neem Leaves Powder 
Table.3 Effect of supplementation of Aloe vera and Neem leaves powder on total protein (g/dl), albumin $(\mathrm{g} / \mathrm{dl})$ and globulin $(\mathrm{g} / \mathrm{dl})$ under different treatment groups

\begin{tabular}{|c|c|c|c|}
\hline Treatments & $\begin{array}{c}\text { Total protein } \\
\text { (g/d) }\end{array}$ & Albumin(g/dl) & Globulin (g/dl) \\
\hline $\mathbf{T}_{\mathbf{1}}$ & $3.11^{\mathrm{a}}$ & 1.41 & $1.69^{\mathrm{a}}$ \\
\hline $\mathbf{T}_{\mathbf{2}}$ & $3.03^{\mathrm{ab}}$ & 1.39 & $1.63^{\mathrm{ab}}$ \\
\hline $\mathbf{T}_{\mathbf{3}}$ & $3.01^{\mathrm{abc}}$ & 1.52 & $1.48^{\mathrm{abc}}$ \\
\hline $\mathbf{T}_{\mathbf{4}}$ & $2.90^{\mathrm{abcd}}$ & 1.49 & $1.40^{\mathrm{bcd}}$ \\
\hline $\mathbf{T}_{\mathbf{5}}$ & $2.83^{\mathrm{bcd}}$ & 1.39 & $1.44^{\mathrm{abcd}}$ \\
\hline $\mathbf{T}_{\mathbf{6}}$ & $2.80^{\mathrm{cd}}$ & 1.50 & $1.29^{\mathrm{cd}}$ \\
\hline $\mathbf{T}_{\mathbf{7}}$ & $2.76^{\mathrm{d}}$ & 1.40 & $1.36^{\mathrm{cd}}$ \\
\hline $\mathbf{T}_{\mathbf{8}}$ & $2.68^{\mathrm{de}}$ & 1.41 & $1.24^{\mathrm{cd}}$ \\
\hline $\mathbf{T}_{\mathbf{9}}$ & $2.54^{\mathrm{e}}$ & 1.37 & $1.17^{\mathrm{d}}$ \\
\hline S.E. & 0.06 & N.S. & 0.08 \\
\hline C.D. @ 5 per & 0.21 & N.S. & 0.26 \\
\hline cent & & & \\
\hline C.V.\% & 4.27 & 8.04 & 10.85 \\
\hline
\end{tabular}

Means with different superscripts differ significantly

Table.4 Effect of supplementation of Aloe vera and Neem leaves powder on Cholesterol, Serum HDL cholesterol and Serum LDL cholesterol under different treatment groups

\begin{tabular}{|c|c|c|c|}
\hline Treatments & $\begin{array}{c}\text { Cholesterol } \\
(\mathbf{m g} / \mathbf{d l})\end{array}$ & $\begin{array}{c}\text { Serum HDL } \\
(\mathbf{m g} / \mathbf{d l})\end{array}$ & $\begin{array}{c}\text { Serum LDL } \\
(\mathbf{m g} / \mathbf{d l})\end{array}$ \\
\hline $\mathbf{T}_{\mathbf{1}}$ & $121.57^{\mathrm{a}}$ & $28.86^{\mathrm{c}}$ & $51.30^{\mathrm{a}}$ \\
\hline $\mathbf{T}_{\mathbf{2}}$ & $118.93^{\mathrm{a}}$ & $29.08^{\mathrm{c}}$ & $48.26^{\mathrm{b}}$ \\
\hline $\mathbf{T}_{\mathbf{3}}$ & $99.75^{\mathrm{cd}}$ & $31.73^{\mathrm{b}}$ & $47.60^{\mathrm{b}}$ \\
\hline $\mathbf{T}_{\mathbf{4}}$ & $102.20^{\mathrm{bcd}}$ & $32.42^{\mathrm{ab}}$ & $47.20^{\mathrm{b}}$ \\
\hline $\mathbf{T}_{\mathbf{5}}$ & $92.57 \mathrm{~b}^{\mathrm{e}}$ & $33.46^{\mathrm{a}}$ & $47.60^{\mathrm{b}}$ \\
\hline $\mathbf{T}_{\mathbf{6}}$ & $104.57^{\mathrm{bc}}$ & $33.13^{\mathrm{a}}$ & $42.70^{\mathrm{c}}$ \\
\hline $\mathbf{T}_{\mathbf{7}}$ & $107.17^{\mathrm{b}}$ & $33.41^{\mathrm{a}}$ & $41.43^{\mathrm{d}}$ \\
\hline $\mathbf{T}_{\mathbf{8}}$ & $97.04^{\mathrm{de}}$ & $33.18^{\mathrm{a}}$ & $40.60^{\mathrm{de}}$ \\
\hline $\mathbf{T}_{\mathbf{9}}$ & $99.71^{\mathrm{cd}}$ & $32.01^{\mathrm{b}}$ & $40.20^{\mathrm{e}}$ \\
\hline $\mathbf{S . E .}$ & 2.13 & 0.35 & 0.39 \\
\hline C.D. @ 5 per & 6.48 & 1.07 & 1.22 \\
\hline cent & & & \\
\hline C.V.\% & 3.57 & 1.95 & 1.56 \\
\hline
\end{tabular}

Means with different superscripts differ significantly 
Table.5 Effect of supplementation of Aloe vera and Neem leaves powder on Triglycerides, Uric acid and Creatinine under different treatment groups

\begin{tabular}{|c|c|c|c|}
\hline Treatments & $\begin{array}{c}\text { Serum } \\
\text { triglycerides } \\
(\mathbf{m g} / \mathbf{d l})\end{array}$ & $\begin{array}{c}\text { Uric acid } \\
(\mathbf{m g} / \mathbf{d l})\end{array}$ & $\begin{array}{c}\text { Creatinine } \\
(\mathbf{m g} / \mathbf{d l})\end{array}$ \\
\hline $\mathbf{T}_{\mathbf{1}}$ & $101.17^{\mathrm{a}}$ & $5.73^{\mathrm{a}}$ & $0.89^{\mathrm{a}}$ \\
\hline $\mathbf{T}_{\mathbf{2}}$ & $100.03^{\mathrm{ab}}$ & $5.03^{\mathrm{c}}$ & $0.80^{\mathrm{b}}$ \\
\hline $\mathbf{T}_{\mathbf{3}}$ & $93.26^{\mathrm{cd}}$ & $5.30^{\mathrm{bc}}$ & $0.83^{\mathrm{b}}$ \\
\hline $\mathbf{T}_{\mathbf{4}}$ & $95.28^{\mathrm{bc}}$ & $5.43^{\mathrm{ab}}$ & $0.82^{\mathrm{b}}$ \\
\hline $\mathbf{T}_{\mathbf{5}}$ & $97.37^{\mathrm{abc}}$ & $5.06^{\mathrm{bc}}$ & $0.84^{\mathrm{b}}$ \\
\hline $\mathbf{T}_{\mathbf{6}}$ & $79.89^{\mathrm{e}}$ & $5.03^{\mathrm{c}}$ & $0.82^{\mathrm{b}}$ \\
\hline $\mathbf{T}_{\mathbf{7}}$ & $98.54^{\mathrm{ab}}$ & $5.70^{\mathrm{a}}$ & $0.81^{\mathrm{b}}$ \\
\hline $\mathbf{T}_{\mathbf{8}}$ & $88.79^{\mathrm{d}}$ & $5.26^{\mathrm{bc}}$ & $0.81^{\mathrm{b}}$ \\
\hline $\mathbf{T}_{\mathbf{9}}$ & $88.15^{\mathrm{d}}$ & $5.13^{\mathrm{bc}}$ & $0.81^{\mathrm{b}}$ \\
\hline S.E. & 1.75 & 0.14 & 0.014 \\
\hline C.D. @ 5 per & 5.27 & 0.39 & 0.044 \\
\hline cent & & 4.30 & 3.101 \\
\hline C.V.\% & 3.24 & $4^{\circ}$ & \\
\hline Means with different superscripts differ significantly & \\
\hline
\end{tabular}

From the data, it was observed that the uric acid was 5.73, 5.03, 5.30, 5.43, 5.06, 5.03, 5.70, 5.26 and $5.13 \mathrm{mg} / \mathrm{dl}$ for the treatment groups $\mathrm{T}_{1}, \mathrm{~T}_{2}$, $\mathrm{T}_{3}, \mathrm{~T}_{4}, \mathrm{~T}_{5}, \mathrm{~T}_{6}, \mathrm{~T}_{7}, \mathrm{~T}_{8}$ and $\mathrm{T}_{9}$, respectively. However it is observed that the lowest uric acid concentration were observed in $\mathrm{T}_{2}$ and $\mathrm{T}_{6}(5.03)$ $\mathrm{mg} / \mathrm{dl}$ with birds that were receiving $1 \%$ A. vera powder and combination of $1 \%$ A. vera powder $+1 \%$ neem leaves powder. All treatments were at par with each other. This might be due to increase the level of aloe vera and neem leaf powder.

\section{Creatinine}

Serum urea nitrogen and creatanine are commonly used to indicate level of renal function and possible damage to kidney architecture (Slunnil, 1974). From the data, it was observed that the creatinine was $0.89,0.80$, $0.83,0.82,0.84,0.82,0.81,0.81$ and $0.81 \mathrm{mg} / \mathrm{dl}$ for the treatment groups $\mathrm{T}_{1}, \mathrm{~T}_{2}, \mathrm{~T}_{3}, \mathrm{~T}_{4}, \mathrm{~T}_{5}, \mathrm{~T}_{6}$, $\mathrm{T}_{7}, \mathrm{~T}_{8}$ and $\mathrm{T}_{9}$, respectively. However it is observed that the lowest creatinine concentration were observed in $\mathrm{T}_{2}(0.80) \mathrm{mg} / \mathrm{dl}$ with birds that were receiving 1 per cent $A$. vera powder and recorded highest cratinine concentration in control group (0.89) $\mathrm{mg} / \mathrm{dl}$. All treatments were at par with each other. This might be due to increase the level of aloe vera and neem leaf powder.

The nitrogenous compounds urea and creatinine are eliminated from the body by the kidneys. The excretion of waste product of the body is minimized indicating maximum utilization of metabolites which promotes an increase in weight and production of more eggs. Sinha et al., (2017); Sonhafonu et al., (2019); Singh et al., (2013) was recorded no significant variation in serum creatinine by aloe vera supplementation in diets of birds. Also Jawad et al., (2014); Obikaonu et al., (2012) reported serum creatinine and serum uric acid levels during this study showed a decrease in their values as the level of neem leaf meal was increased in the ration.

\section{References}

Basak B., A. H. Pramanik, M. S. Rahman, S. U. Tarafdar and B. C. Roy, 2002. Azolla 
(Azolla pinnata) as a feed ingredient in boiler ration. Int. J. Poult. Sci., 1(1/3): 2934.

Eevuri T. R. and R. Putturu, 2013. Use of certain herbal preparation in broiler feed A review. India, Rajendranagar, Hyderabad University, college of Veterinary Science. Vet. World, 6(3): 172-179.

Fallah R., 2014. Effects of supplementing Aloe vera gel and garlic powder on blood biochemical parameters and immune response of broiler. Journal of Medicinal Plant Research. 8(32): 1035-1039.

Jawad Z, M., M. U. Younus, R. Rehman, A. Munir, W. Maqbool, S. Shahzad, K. Masood, K. Muhammad, 2014. Effect of Azadirachta indica on the hepato-renal functions in broilers chickens. The journal of animal \& plant sciences, 24 (4): 10121018.

Mehala, C. and M. Moorthy, 2008. Effect of aloe vera and curcuma longa (Turmaric) on carcass characteristics and biochemical parameters of broiler. International J. of Poultry Sci., 7 (9): 857-861.

Nodu, M. B., M. Okpeku, Z. A. Akpovetai and D. O. Iroegbu, 2016. Evaluation of Azadirachta indica leave extract on hematology and biochemical profiles, organs weight and growth parameters of broiler chickens. Journal of new sciences, 32(5): 1879-1884.

Obikaonu, H.O., I. C. Okoli, M.N. Opara, V. M. O. Okoro, I.P. Ogbuewu, E.B. Etuk and A.B.I. Udedibie, 2012. Haematological and serum biochemical indices of starter broilers fed leaf meal of neem (Azadirachta indica). Journal of Agricultural Technology, 8 (1): 71-79.

Prasad, C. M. and A. K. Sen, 1993. Study the effect of four different growth promoters on performance of broiler. Poult. Advisor, 26 (7): 49-52.

Samarth, V. R., D. G. Jagtap., N. P. Dakshinkar., M. V. Nimbalkar and M. D. Kothekar, 2002. Effect of Ashwaganha root powder (Withania somnifera) on performance of broiler. India Vet. J., 79: 733-734.

Shihab, I. M., 2017. Effect fed varying dietary levels of neem powder of broilers on serum biochemical and intestinal morphology. IJABR, 7 (4): 739-745.

Singh, A., Neeraj and J. Prasad, 2013. Effect of dietary supplementation of Tulsi (Ocimum sanctum) leaf powder on oxidative stress marker in broilers. Journal of Animal Research, 3 (2): 137140.

Sinha S., M. Sarma, R. Nath, K. B. Devchoudhury, 2017. Changes in serum biochemical constituents of Pati ducks (Anasplatyrhynchos domesticus). The Pharma Innovation Journal 6, 223-225.

Slunnil, M. S., 1974. A review of the pathology and pathogenesis of acute renal failure. $\mathbf{J}$. Clin. Pathol, 27: 2-10.

Snedecor, G. W. and W. G. Cochran, 1994. Statistical methods $\left(8^{\text {th }}\right)$ edition. Culcutta, India: Oxford and IBH publishing Co.

Sonhafouo, V. M., J. R. Kana and K. N. Dongmo, 2019. Effects of graded levels of Azadirachta indica seed oil on growth performance and biochemical profiles of broiler chickens. Veterinary Medicine and Science, DOI: 10.1002/vms3.162.

Trincha S., C., A. Cernea, Arion and L. Ognean, 2012. The relevance of mean blood samples in hematological investigations of broiler chickens. Veterinary Medicine, 69(1-2): 209-214.

\section{How to cite this article:}

Gadekar, S. D., S. D. Chavan and Shegokar, S. R. 2020. Effect of Using Aloe vera (Aloe barbadensis) and Neem (Azadirachta indica) Leaves Powder on Blood Biochemical Parameters in Vanraja Poultry Birds. Int.J.Curr.Microbiol.App.Sci. 9(10): 1324-1332. doi: https://doi.org/10.20546/ijcmas.2020.910.159 